For the Review of faith \& International affairs 2018. Professor Anne Stensvold, and Ingrid Vik, IKOS, University of Oslo

\title{
Religious Peacemakers on the International Scene: Hopes and Motivations
}

By Anne Stensvold and Ingrid Vik

\begin{abstract}
Interreligious dialogue is an often-neglected part of the tool kit of peacebuilding and conflict resolution. It involves religious leaders in a hybrid function as diplomats trapped somewhere between the secular and religious realms. But religious peacemaking is not for everyone. Who is involved and what are their motivation? Unlike professional diplomats religious leaders have no formal attachment to state politics but represent a religious organization of some kind - a church, a congregation, a religious NGO. What informs their commitment to peace, and how do they understand their contribution? In this article, we distinguish between theological and political peace dialogues, and trace the underlying moral and social concerns that motivate the religious entrepreneurs who initiate and moderate interreligious dialogues for peace. Informed by the observation that religious diplomacy is not for everyone, we develop a model of different religious sensibilities on a scale from those who see interreligious dialogue as a meaningful religious engagement on the one end, and on the other we find those who see every encounter with 'the religious other' as an opportunity to "tell the Truth". Underlying each position we find specific religious values and different attitudes to politics and man's position in the world. Our aim here is not to give a comprehensive account of religious actors in peacebuilding but to contribute to a better understanding of the participants in interreligious dialogue. What we find is that religious diplomacy is inspired by a kind of personal motivation which is entangled with particular worldviews and understanding of religion.
\end{abstract}

Those who wish to give interreligious dialogue a proud historical legacy usually trace its roots back to the 1893 and the world exhibition held in Chicago that year. ${ }^{1}$ Interreligious dialogue in our sense of the word, however, did not commence until the 1960s and '70s. From the mid-1980s onwards dialogue has evolved into a small but significant part of the regular activities of major religious traditions, and has by now become a fixture of international relations. But despite the many interreligious initiatives and the amount of resources allocated for such activities, analyses of interreligious dialogue participants and their strategic reasoning is a missing perspective in research. This article is based on critical analysis of a number of published interviews and biographies, as well as conversations with central actors and monitors. In addition, we draw heavily on co-author Ingrid Vik's professional experience dealing with religious diplomacy on several levels. ${ }^{2}$ Our aim here is not to give a comprehensive overview of religious actors engaged in peacebuilding but to contribute to a better understanding of some of the entrepreneurs behind interreligious dialogue projects for peace. Who are they? And what motivates their engagement?

In order to address these questions we approach religious dialogue as a religious rather than a political phenomenon. After a brief clarification of what we understand by 'interreligious dialogue' and 'religious diplomacy,' we take a look at the Nobel Peace laureate of 1929 Nathan Söderblom (1866-1931). A celebrated scholar and appointed archbishop of the Swedish Church in 1914, we regard him as a main source of inspiration of today's religious peacemaking.

\section{The Who-Where-and-What of Dialogue and Interreligious Diplomacy}

Religious diplomacy and interreligious dialogue are commonly referred to as second track diplomacy, i.e. unofficial dialogues and activities attempting to influence ongoing 
For the Review of faith \& International affairs 2018. Professor Anne Stensvold, and Ingrid Vik, IKOS, University of Oslo

political peace processes (Harpviken \& Røislien 2008, 361). ${ }^{3}$ There are different types of interreligious dialogue, two of which are relevant in the present context: the theological and the political. The theological approach involves only religious participants, and focuses on religious values and theological concerns. This kind of dialogue may serve as a preparatory stage before more pragmatic and political talks can take place. Here we are concerned with interreligious dialogues in peace processes, and what Neufeldt (2011) refers to as 'political dialogue,' which is built on the underlying assumption that these dialogues will enhance mutual understanding, increase respect and improve relations among religious leaders, and translate into better interreligious relations on the ground. This is also why Muhammad Khatami, former president of Iran, as well as Kjell Magne Bondevik, former Norwegian prime minister, prefer dialogues, which also include politicians. ${ }^{4}$ The political motivation behind it is to seek to broaden the support for peace processes among the religious leadership, the underlying assumptions being that religious leaders have moral authority and local influence. Interreligious dialogue in this sense is used instrumentally to strengthen international peacemaking processes. It is pragmatic and goal oriented and may conveniently be referred to as religious diplomacy.

Before we look closer at interreligious dialogue we would like to point the reader's attention to the structural diversity of religion-state relations (from theocracy to laïcité) and how this affects religious diplomacy. This is not the place to problematize this further, but suffice it to say that there seems to be a positive correlation between interreligious dialogue for peace, and support of an international order of binding agreements, international law, and the United Nations. Engagement in development cooperation is also a common trait, as well as a firm historical basis in Christianity. In recent years, however, this pattern has been broken as other countries, such as Jordan, ${ }^{5}$ have developed serious engagement in interreligious dialogue.

Religious diplomacy may conveniently be described as an emerging institution consisting of a variety of participants who often have their own NGOs (non-governmental organizations), to local religious leaders. Our focus is on the international monitors and their religious NGOs. Like other NGOs these are autonomous organizations oriented towards specific problems (e.g. peace), and usually have informal links to larger (religious) organizations (e.g. a national church). NGOs were established in ever-greater numbers in Western democracies from the 1960s onwards. Not surprisingly, this is reflected in the UN context where Christian NGOs are overrepresented in relation to their relative numbers as compared to other religions, such as, for example, Islam (Haynes 2014, 21). The reasons are political as well as economic, as a strong civil society sector is measured by NGO activity, a characteristic feature of liberal democracies. Religious organizations from Northern Europe are disproportionately active on the international scene, partly because of state sponsoring (e.g. Vik and Endresen 2017). When these governments are also more prone to support religious diplomacy for peace, it may be due to deep-set cultural patterns of interaction between the government and state church, which sets precedence for the state's involvement in church affairs and to use religion and religious actors as means to further government policies, e.g. when Norway sends delegations including representatives from the former state church to international UN conferences. ${ }^{6}$ This is typical of countries with long standing state church traditions, e.g. the Russian Orthodox Church which actively furthers the country's international agenda (Horsfjord 2017). This particular type of religio-political entanglement often escapes media attention (Hurd 2008), but does in fact represent a third avenue of statereligion-relations, more often than not grounded in an informal recognition of a longstanding tradition of state-religion relations.

The participants in religious diplomacy can be described as men who channel their religiosity through their belief in dialogue with 'the religious other.' ${ }^{7}$ (Religious leadership is 
For the Review of faith \& International affairs 2018. Professor Anne Stensvold, and Ingrid Vik, IKOS, University of Oslo

a man's world, as much as war, peace, and diplomacy.) Theirs is a deeply personal commitment, often with roots in private experiences. An illustrative example is Trond Bakkevig, a Norwegian Lutheran priest, who has been the convener of an inter-religious council in Israel/Palestine since 1997. He spent parts of his childhood in the region, and in his autobiography he says that this may explain his strong wish for peaceful co-existence between Israelis and Palestinians: "Perhaps that was the hope that made me want to return? Perhaps there was a sense of commitment to the schoolmates and others I had become familiar with?"8 Or the motivation may be more explicitly religious in character, as former Norwegian primeminister Kjell Magne Bondevik put it: "My main inspirations to combat an unjust and troubled world are God's love for his creation and the example of Jesus Christ. I still believe that love for my neighbor is the strongest power that any political decision maker can yield anywhere in the world." "With emotional commitment such as this comes a certain moral urgency, which lends a personal touch to their engagement. To put it bluntly, they invest in personal relationships and are more than average network builders.

Another characteristic, which sets these religious diplomats apart, is their ambiguous status. Whereas professional diplomats are state department employees and are obliged to promote government policy, religious diplomats in most cases have no formal status within the state bureaucracy but collaborate on a freelance basis. ${ }^{10}$ Instead they enjoy an in-between status when they are co-opted by a state through project funding or formal state-religion arrangements, but they are first and foremost representatives of a religion or a religious tradition with which they identify emotionally and personally. A common denominator among them is that they regard religion as necessary for public morality and a prerequisite for a good society. To them, a secular policy that excludes religion is an abomination and a catastrophe waiting to happen. So this is where religious diplomats come into the picture, to rectify the wrong and make sure that religion is included in peace and conflict resolution. Man is not perfect, but needs correction and guidance that religions can provide. This is what, in their own eyes, makes political engagement so important.

\section{Historical Roots: Archbishop Söderblom}

The roots of religious diplomacy as we know it can be traced back to the interwar period and Nathan Söderblom, a Nobel Peace laureate (1929), and Swedish archbishop (19141931). This is not to say that Söderblom was alone in seeing interreligious dialogue as a peacemaking tool, and ideas about religious tolerance and pluralism were also expressed in other religious contexts, e.g. Mahatma Gandhi in India. But Söderblom's combination of theoretical thinking and organizational initiatives makes him uniquely influential in Protestant thinking about these issues. ${ }^{11}$ His organization, the Ecumenical Council, was a precursor of the World Council of Churches (1948). ${ }^{12}$ Even though his peace initiative was limited to intraChristian dialogue among the warring countries in the First World War, Söderblom's intellectual heritage is more far-reaching. As a scholar he was a proponent of a particularly open approach to other religions, a view which was based on his belief in a common core of 'holiness' shared by all world religions.

Holiness is the great word in religion; it is even more essential than the notion of God. Real religion may exist without a definite conception of a deity, but there is no real religion without a distinction between holy and profane. Söderblom (1914) ${ }^{13}$

This position is known as perennialism. Among Christian theologians, it is associated with what is usually found in connection with liberal Christian thinking. ${ }^{14}$ The Catholic Church expressed a similar view during Vatican II (1962-65) with one important difference: perennialism proclaims an essential likeness and regards different religions as various 
For the Review of faith \& International affairs 2018. Professor Anne Stensvold, and Ingrid Vik, IKOS, University of Oslo

manifestations of the (same) holy. The Catholic stance is more guarded, stating that the Church "rejects nothing that is true and holy in these religions," and that these religions "often reflect a ray of that Truth" ( $\$ 2$ Nostra Aetate, Declaration on the relation of the Church to other religions, 1965).

Söderblom's understanding of holiness as a common core of religion derived from his work in comparative religion. The goal of his comparison was informed by a deeply religious belief in God as the benign creator whose traces can be seen in his creation, especially in religious traditions. The holy was understood as "that which reveals itself" and for Söderblom this implied that other religions could give new insights and deeper understanding of his faith. But more importantly, it provided a basis for treating various religions as equally significant and allowed researchers to study "what the believers conceived as holy rather than studying The Holy” (Tuckett 2016, 243).

In 1914 Söderblom was appointed archbishop of the Swedish Church (a Lutheran state church), and left his professoriate. His engagement for peace started as a reaction to WW1 when he invited Christian leaders from across the world to meet in Uppsala, his bishop's residence in neutral Sweden on the 14th of November 1914. It was not an immediate success. 32 church leaders attended, two from the Netherlands and Switzerland, the rest from Scandinavia, and to Söderblom's disappointment none from the warring parties (Jonson 2016, 223). His engagement continued, and in the interwar period he established the Ecumenical council and eagerly supported the League of Nations.

Söderblom's peace activism started when he became archbishop, and was accompanied by a reorientation from an intellectual quest to identify a common core of holiness in all religions to a social engagement, which was framed searching for reflections of Christ in the world. In order to understand Söderblom's peace activism it is necessary to see him in the context of liberal Protestant theology. Like his fellow liberal theologians, he regarded Christianity not as "the religion of the Book, but a historical revelation, perfected in Christ" (Andersson 2006, 8). This Christ-centered theology is radically different from the socalled fundamentalist strains of Christian thinking. It implied a reorientation away from the Bible towards "the living Christ," and had radical consequences for the way these liberals conceived of God and the religious other. Its historical roots can be traced to the introduction of historical-critical Bible exegesis and the liberals' search for the historical Jesus. This pursuit was not just an intellectual challenge but a deeply religious quest for God in this world, and developed in the tale-wind of historical-critical method in 19th century theology. It became a hallmark of liberal Protestantism and implied a reorientation away from a vertical, heavenward gaze searching for God up above, to a horizontal gaze looking for God in this world; among fellow humans. As such liberal Christianity provides a logical basis for interreligious dialogue and encounters with 'the (religious) other.'

In his Nobel speech delivered in Oslo on the 10th of December 1929, Söderblom explained how religion can contribute to peacebuilding:

The causes of the war (WW1) and the purely political measures for achieving peace were not to be discussed. The aim was to examine what the different churches could achieve in the struggle against war, and how they could bring about the proper state of mind or climate needed for better international understanding.... We do not believe with Socrates that man does what is right because he knows it to be right, but we must agree with the philosopher in that man needs to know what is right before he acts. (Söderblom 1929)

Unlike today where interreligious dialogue is seen as a part of the political realm and classified as a soft power in international relations (Haynes 2016), Söderblom envisaged 
For the Review of faith \& International affairs 2018. Professor Anne Stensvold, and Ingrid Vik, IKOS, University of Oslo

religion on the world stage as a separate and independent entity. His vision for The Ecumenical council was as a special forum for religious peacemaking separate from secular power politics. Such a model mirrors the Lutheran distinction between the earthly and the spiritual kingdoms. Söderblom's biographer Jon Jonson puts it like this: "The Lutheran distinction between the earthly and the spiritual kingdoms had marked Sweden for four hundred years. The church was not accustomed to criticizing the government, much less commenting it" (Jonson 2016, 241). Perhaps we can say that he tried to make the church-state divide he knew from Sweden a universal model securing religious independence but at the same time securing religious influence in international politics.

\section{Two Religious Cultures: Dialogue Meetings and Missionary Work}

After the close of the Second World War and the establishment of the United Nations, international cooperation increased significantly in all sectors, including religion.

Söderblom's legacy was taken up by the World Council of Churches (WCC). This was, as we have seen, a Protestant initiative to unite all Christendom in one organization. The established Protestant churches and Orthodox churches became members but the Catholic Church declined and joined half way as an observer. The evangelical, Pentecostal, and charismatic churches have their own international umbrella organizations, such as the Lausanne movement (1974) and the World Evangelical Alliance, with the American evangelist Billy Graham as a main source of inspiration. ${ }^{15}$ Whereas WCC embraces religious pluralism/relativism, and has been actively present at the UN from the start (Lehmann 2015), a fundamentalist approach to inter-religious matters is rooted in a different, almost opposite approach to the religious other. For them an encounter with the religious other is not an occasion to strengthen and deepen one's own faith but an occasion to follow Christ's missionary dictum and bring his message to the world (Mathew 28:19). The whole world is a missionary ground, and the religious other is a potential convert.

This divide within Christendom amounts to almost contradictory worldviews, with liberal oriented churches one the one end of the spectrum and fundamentalists on the other. ${ }^{16}$ In between we find the conservatives in an intermediary position combining traits form both, e.g. the Catholic Church, which combines conservative family values with a progressive social teaching. ${ }^{17}$ Moreover, these positions are closely associated with different kinds of religiosity with the liberals channeling their religiosity into the search for social justice, respect, and equality, the fundamentalist-traditionalists focusing on salvation, while the intermediary position is characterized by ritual observance and communal church activities and varying degrees of humanitarianism and social reformism. We find the majority of established Protestant Churches on the liberal pole, while the traditionalist pole is dominated by Pentecostal and fundamentalist churches. ${ }^{18}$ In the middle of the spectrum we find the Orthodox and Catholic Christianity, as well as some moderate evangelicals.

Obviously the difference in values is far more complex than this crude summary suggests, but the significance of differing values within organized Christianity translates into political divide between the liberals who are valued collaborator for liberal-democratic governments, and the conservative churches which have a long history of collaborating with undemocratic regimes. In this connection it should be noted that over the last decades liberal Christian churches have seen their constituencies waning, while evangelicals and Pentecostals as well as Mormons and Jehovah's Witnesses have been successful in their missionary efforts and have spread their own version of Christianity and count millions of converts in Africa, Asia, and South America. ${ }^{19}$ When it comes to sexuality and moral issues the Pentecostal churches share their 'family values' with the Russian Orthodox and the Catholic Church. ${ }^{20}$ Michael Barnett explains the rift within Christianity as a theological difference between those who wish to save souls versus those who put human lives first: "In the nineteenth century 
For the Review of faith \& International affairs 2018. Professor Anne Stensvold, and Ingrid Vik, IKOS, University of Oslo

many religious agencies, especially those with a missionary component, desired to save souls as their main primary goal; by the end of the century, though, some downplayed this dimension in preference of saving lives and change societies" (Barnett 2012, 166). Needless to say, religious diplomats by definition belong to the first category.

The particularities of Christianity aside, a similar divide can be found in all religions, and goes under various names: liberal versus conservative, reform willing versus traditionalists, modernist versus fundamentalist, etc. What is at stake here is differing worldviews between those who accept the religious pluralism they observe around them, and those who persist in their own religion's total hegemony. The influential sociologist of religion, Peter Berger suggests the relativism/fundamentalism dichotomy as more illuminating. He describes the difference in worldview between liberals and (conservative) evangelicals as a clash between "the relativist view that finally all religions are equally true... and the aggressive and intolerant fundamentalist claim to absolute truth" (Berger 2010, 10). In should be noted that Berger adopts a functional view and does not distinguish between religion and non-religion, and his categories therefore include secular worldviews (there can be secular fundamentalists and religious relativists). The relativists see a purpose in building bridges and engage in peacemaking, while the latter are too close-minded (extremist) to have constructive encounters with the religious other. In practical life (and politics), this dichotomy translates into respect for the religious other or lack thereof. When we write about this split and refer to clashing values within the world religions, it is of course an over simplification. Between these two extremes - the accommodating and the confrontational-we envisage a continuum where liberal and conservative; reformist and traditionalist; pragmatist and extremist are at the extreme opposite ends.

\section{A Pragmatic Muslim View}

As already mentioned, a similar split is found within every religious tradition, and within religious organizations. In many ways the promoters and moderators of interreligious dialogue often have more in common with each other than they have with their co-religionists. They emphasize equality, and also share important features with values and ideas expressed in the Declaration of Human Rights (1948). In Islam former Iranian president Muhammed Khatami (1997-2005) is a representative of the dialogue-oriented camp within his own Shia tradition.

In 1999 president Khatami took the first initiative to increase interreligious dialogue. Originally known as 'Dialogue among Civilizations,' this is today a body within the UN, the Alliance of Civilizations (Haynes 2017). The name was intended to counter Huntington's 'clash of civilizations,' and can be seen as an attempt on Khatami's part to tap into the heritage of Iran's millennia Old Persian civilization. From his perspective intercivilizational/religious dialogue provided a political opportunity to break the Shia republic's isolation and re-enter the international community. Khatami never sought to create a new UN body, but following 9/11 others saw his initiative as a welcome opportunity, and in 2005 the Alliance of Civilizations was created following an initiative from the then prime ministers of Spain and Turkey. More important in the present context is Khatami's (personal or religious) motivation, which he expressed in a humanistic language, explaining how empathy, compassion and understanding are prerequisites for dialogue: "Without the will for empathy, compassion and understanding there would be no hope for the prevalence of order in our world" (Khatami 2000, 26). To Khatami, individuals who engage in these dialogues are representatives of their respective civilizations and carry its values. It seems that to Khatami these civilizational traits have an intrinsic quality which makes possible "a metahistorical discussion of eternal human questions - such as the ultimate meaning of life and death or 
For the Review of faith \& International affairs 2018. Professor Anne Stensvold, and Ingrid Vik, IKOS, University of Oslo

good and evil - ought to substantiate and enlighten any dialogue on political and social issues" $(2000,26)$.

Dialogue between civilizations was an opportunity to introduce "spiritual experience and faith" into international politics, and was seen as a way to counteract Western secularism. However, after Khatami withdrew from politics in 2009 his attempt at balancing political and religious power was struck from Iran's foreign policy agenda, and since 2015 Iranian media have been barred from mentioning his name. ${ }^{21}$ Since this injunction was introduced under the otherwise "liberal" president Hassan Rouhani, it must be interpreted as a sign of the influence of the conservative supreme leader, Ali Khamenei. Since 2009 Khatami has effectively been under house arrest and his interreligious NGO is no longer active. ${ }^{22}$

The split between conservative-traditional and liberals is also found in Sunni Islam where several competing groups are locked in a battle for definitional power. The battle also involves states, notably Saudi Arabia, which sponsors fundamentalist preachers and congregations worldwide (Gallarotti, Giulio and Al Filali 2012). Saudi Arabia is also actively involved in interreligious dialogue through the Vienna based centre, The King Abdullah bin Abdul-Aziz's Center for Intercultural and Interreligious Dialogue (KAICIID). The centre is not exclusively a Saudi enterprise, however, but is also supported by Austria and Spain. ${ }^{23}$ Nevertheless, there can be little doubt that the Saudi state religion is fundamentalist Wahhabi Islam, and that the centre with its Saudi ownership is locked in a problematic ambiguity.

\section{A Catholic Approach}

The liberal versus conservative dichotomy, which divides Protestant churches and splits Islam in radically different schools of thought, is surely present also among Catholics. But unlike other religious traditions, the hierarchical structure of the Catholic Church ensures official unity as official church policy is entirely orchestrated by the pope and the Vatican. Since the Catholic Church is also a recognized state (the Vatican state) with diplomatic relations with almost all UN member states, and is a "permanent observer state" at the UN. The pope himself is the most efficient diplomat (Stensvold 2017), but in addition to its diplomatic corps, the Catholic Church is also actively involved in peace initiatives via Catholic NGOs such as Sant'Egidio.

On the 23rd of October 1986 a symbolically significant event took place when the pope John Paul II invited religious leaders to join him in Assisi to pray for world peace. Although the meeting took place in a spirit of communion, with participants sharing meals and attending talks and public events together, the prayers took place separately. In his speech the pope stated what afterwards has become a shared understanding to which all participants in interreligious dialogue may subscribe:

The fact that we have come here does not imply any intention of seeking a religious consensus among ourselves or of negotiating our faith convictions. Neither does it mean that religions can be reconciled at the level of a common commitment in an earthly project, which would surpass them all. Nor is it a concession to relativism in religious beliefs. ${ }^{24}$

The main achievement of the Assisi meeting was as a public demonstration of interreligious harmony. It was a hugely successful media event, particularly for the pope and the Catholic Church. Almost like a theatrical tableau, the participants made a colorful image of religious diversity. By the same token the pope who hosted the event managed to present himself as the head of religious leaders from across the world. Behind the scene, however, a particularly effective Catholic organization was hard at work, Communità di Sant'Egidio. Today Sant'Egidio is the most influential Catholic peace broker, but it started out in a more 
For the Review of faith \& International affairs 2018. Professor Anne Stensvold, and Ingrid Vik, IKOS, University of Oslo

modest manner as a soup kitchen for Rome's homeless poor in 1968. The initiative came from a group of students with an acute awareness of solidarity and compassion for the poor (Riccardi 1997, 105). "War is the mother of all poverty," Sant'Egidio's founder and president, Andrea Riccardi answered when asked about the connection between Sant'Egidio's origins and its international peace engagement (Riccardi 1997, 94).

In the 1990s interreligious dialogue developed into what we will refer to as 'religious diplomacy.' This was not new to the Catholic Church, however, which has its own privileged platform in the international political system where it enjoys the status of an independent state (The Vatican state or the Holy See). With diplomatic relations with 177 states across the world, ${ }^{25}$ the pope was already involved in religious diplomacy, and has been for hundreds of years, ever since the Papal state was part of the European state formation. However, lay initiatives like those initiated by Sant'Egidio are more flexible and an effective addition to Vatican diplomacy. Since the 1980s, this Catholic NGO has been actively involved in peace facilitation in countries such as Mozambique (largely sponsored by Norway), Guatemala, Sudan and Algeria. Extensive collaboration with local Catholic congregations and a shared Catholic identity are keys to Sant'Egidio's success. It is worth noting that Sant'Egidio, as a part of the Catholic Church, is also a part of its authority structure. Alternatively, as Riccardi explains, it is an independent agent but because it is a Catholic organization, Sant'Egidio maintains links with the church hierarchy and seeks the bishop's approval (Riccardi 1997, 88). In this case the local bishop is the pope (the bishop of Rome).

Like other religious NGOs involved in peacemaking Sant'Egidio also works closely with state authorities, and whenever their engagement has political or diplomatic consequences "we inform the Italian ministry of foreign affairs." Riccardi's own political role as Italian Minister of Foreign Affairs (2011-2013) makes him a typical representative of the religious diplomats we are concerned with here. The importance of personal religiosity is a recurring theme; many religious diplomats have a clerical background as well experience from political office, and pursue their work for peace through their own NGO. Riccardi ticks all boxes except that he is not a cleric but a professor of history. Like any other diplomatic field, the success of interreligious peacebuilding relies on human relationships and personal networks, as illustrated by Sant'Egidio's record of accomplishment and Riccardi's double role as religious actor and politician. This is not unique, however; Tony Blair is a case in point, not to mention Khatami or Bondevik, just to mention a few.

Riccardi's own motivation for engaging in interreligious peace talks is solidarity with the poor and compassion with human suffering (Riccardi 1997, 91). It seems fair to say that his interest in the religious other is not a perennialist search for 'the holy' unless his intense identification with human suffering can be compared to the feeling of "awe" that Söderblom associates with the holy. In this regard Riccardi has more in common with Khatami who also sees dialogue as an occasion to demonstrate and cultivate mutual respect rather than seek answers to existential questions. Needless to say, this is also core value in professional diplomacy. The added value of religion here is hard to see, apart from bringing religious leaders into political processes and thereby engaging a larger part of civil society.

\section{The Qualities of the Religious Diplomat}

So far, we have identified three religious attitudes to peacemaking: Söderblom's perennialism, Khatami's pragmatism, and Riccardi's solidarity. The motivating force behind these positions can be described accordingly as (1) those who are motivated by an existential search for God in the encounter with the religious other, although in Khatami's case this was described in civilizational terms, (2) those who see their own religiosity as a useful tool to reach political goals, and (3) those who have an emotional commitment to humanity and feel a special loyalty or empathy with the religious other. The latter position can be explained as a 
For the Review of faith \& International affairs 2018. Professor Anne Stensvold, and Ingrid Vik, IKOS, University of Oslo

search for 'the holy' in this world, and has more in common with perennialism than it has with the pragmatic approach, which seems to have a limited religious dimension.

Nevertheless, the search for 'the holy' does not necessarily entail a perennialist theology of sameness. The encounter with the religious other in a dialogue setting can also be an occasion to deepen one's own faith, as David Rosen, rabbi and dedicated peace activist puts it: "Participating in interreligious dialogue deepens my own faith and understanding of who I am. But it also enables me to encounter the presence of the Divine beyond my own Tradition and to perceive it from different perspectives." 26

The three kinds of motivation behind interreligious dialogue are not static categories but crisscross and overlap according to the requirements of the situation, but together they represent a bundle of values and aspirations that set most actors in interreligious dialogue apart from professional diplomats. In this connection, it should be noted that not all professional diplomats have a secular worldview, and that such personal values and presuppositions may influence their professional judgments. However, professional diplomats are not asked to express their personal views - be they religious or not — but promote the interests of the government they represent.

Who are these individuals who choose to channel their religiosity into inter-religious dialogue and believe that they can contribute to world peace? How do they understand their particular mission within the broader framework of international politics? According to Douglas Johnston, faith-based diplomats, as he calls them, has five unique qualities or assets that set them apart from professional diplomats. Although they may profit from training in secular disciplines like conflict analysis, negotiations, and diplomatic communication, it is their personal faith which sets them apart and gives them an added value as peacemakers because "they recognize perhaps more fully that than secular counterparts that there are limits to human understanding" (Johnston 2003, 17). It might be noted that Johnston envisions these diplomats as state department employees, and unlike "our" religious diplomats, they are representatives of the state. But despite this difference, Johnston's list of qualifications corresponds largely to the ideals of religious diplomats. Especially informative is the way he frames personal faith as a kind of expert knowledge. We may presume that faith-based diplomats should represent their country's religion, but what about multi-religious countries like India, with a secular constitution and multi-religious population? Should India have Hindu as well as Muslim diplomats according to their percentage of the population? Johnston has an instrumental view on faith, which can be understood in two ways: either it relies heavily on a perennialist understanding (Söderblom) which ultimately defines all religions as varieties on the same, or 'faith' is implicitly understood as Christian faith. The latter view is probably how Johnston and his followers see it, since the vast majority in the field of 'faithbased diplomacy' are advocating for a greater role for Christian faith in U.S. foreign policy.

Johnston presents five qualities that illustrate the potential value of bringing faith into diplomacy. Firstly faith based diplomats are uniquely useful since they have access to spiritual resources (e.g. praying, fasting, forgiveness, and refer to the Holy Scriptures with ease). Knowledge of one's own religious tradition allows the religious diplomat to point out similarities with other religions and thereby contribute to building trust and thereby pave the way for better communication. Secondly, religious diplomats have spiritual authority, which gives them more influence in peace talks. Their legitimacy derives either from "their ties to a credible religious institution or through trust through evoked by a personal spiritual charisma" (Johnston 2003, 16). The charisma at stake here seems more tied to the supposedly higher moral standards of religious leaders than their personal faith.

Third, religious diplomats have an ingrained respect for religion, which other diplomats may lack. Here we would like to point out that when Johnston refers to "respect for religion" he speaks about religion, not just as a universal category, but also as a generic thing. 
For the Review of faith \& International affairs 2018. Professor Anne Stensvold, and Ingrid Vik, IKOS, University of Oslo

Although Johnston distances himself from perennialism stressing that religious diplomats "do not seek common ground by reducing faith to its lowest common denominators but by appealing to those from different traditions on the basis of the peacemaking warrants that exists within their respective theologies" (Johnston 2003, 17). Here Johnston implicitly asserts that faith based diplomats share an ingrained characteristic, which other diplomats are lacking, namely their respect for (other) religions. It seems to us that Johnston presupposes the existence of a common religious identity or a recognizable characteristics shared by all people of faith, but the meaning of this remains obscure. The reification of the category of 'religion' is a broader problem in the field of interreligious dialogue - for the most part, it is considered in terms of theological ideals and cherry-picked 'shared values.' Peacemaking according to Johnston requires that the participants "exist within their respective theologies" and focus on the matter at hand. Thus, we may well wonder which additional qualities or qualifications Johnston's faith based diplomats bring to the table and how their discourse actually differs from that of other diplomats - unless of course the notion of a shared religious identity comes into play.

Fourth, faith-based diplomacy has a more nuanced approach to peacemaking since all religions recognize the limits of human understanding in Johnston's view. This amounts to an assertion that all religions share an understanding of man as an imperfect being, and expressed by such values as humility and critical self-reflection. Here one may ask in what sense an awareness of human shortcomings is a quality restricted to religious individuals. Johnston's fifth and last point is that religious diplomats have a special, religious calling, which makes them more likely to persevere where other diplomats would give up. As long as it remains unsupported by rigorous empirical data, this amount to little more than to wishful thinking.

When Johnston emphasizes a shared religious identity and disregards the perennialist quest for essential sameness, his approach tallies particularly well with Khahami's pragmatism, and the by-now institutionalized distinction between theological and political interreligious dialogue goals (e.g. Neufeldt 2011). However, Johnston's optimistic vision of what religious diplomacy can achieve relies on an unfounded assumption that religion plays a more central part in (non-Western) countries than hitherto acknowledged (Johnston 1995). However, his claim that diplomats with a personal faith are an unused source of trust and mutual understanding is more practical and tallies well with our own impression that religious faith may be a door opener in dialogue - like any other shared interest for that matter. However, our main concern is with the way that Johnston frames faith, namely as a kind of expert knowledge. Such an instrumental approach raises deeply problematic questions about representativity, and whose religion a religious diplomat gives voice to.

Johnston's vision was briefly realized under Obama when a special office for religious affairs in the state department was established in 2013. It was abolished by the Trump administration. ${ }^{27}$ Johnston's vision may conveniently be summed up as an attempt at putting the personal religiosity of diplomats to good use. It was not engaging religious organizations and leaders in state-initiated peace processes, which has been our focus here. Nevertheless, his list corresponds well with the self-image of religious leaders participating in interreligious peace dialogue. It is also reflected in the hopes and expectations of those politicians and professional diplomats who invite them in and welcome their contribution. In our experience, however, their expectations are more moderate and realistic, tempered by experience and tailored to the audience, but always convinced that no lasting peace is possible without them.

\section{Religious Dialogue As We Know It}

More than thirty years after Assisi, where the pope defined what interreligious dialogue is not about (not seeking a religious consensus or make concessions to relativism in religious beliefs), interreligious dialogue has evolved into something. In addition to a strong 
For the Review of faith \& International affairs 2018. Professor Anne Stensvold, and Ingrid Vik, IKOS, University of Oslo

conviction that religion has an important role to play in peace processes, the religious leaders who engage in peacemaking share a tacit agreement about having a shared religious identity, which effectively sets them apart from their non-religious (secular) adversaries. This is not the planned outcome of prayer meetings as the pope perhaps envisaged in 1986, but an unintended effect of 30 years of interreligious dialogue. However, this shared religiosity does not include all religions. After all, religious diplomacy is nor for everyone. Much like secular politics where left and right may have little in common, so also with the religious field. The divisions are, as noted above, not only between different religions-Buddhism, Christianity, Islam, etc. More important in the present context is the division within religions. Cutting across the world religions, ${ }^{28}$ there is a sharp divide between those who see the religious other as a given fact and look for pragmatic solutions, and those who see the other as a problem and express their concerns either in a rhetoric of victimization or (violent) protest. The latter are typically not engaged in interreligious dialogue, and are often overlooked or excluded as extremists and therefore not representative of true religion-despite the political need to include them.

Before 9/11 interreligious dialogues for peace initiatives were predominantly sponsored by Western states and involved liberal minded religious leaders. In the last 15 years or so countries in the Muslim world such as Jordan, Qatar, Saudi Arabia, and plenty of others have invested heavily in interreligious initiatives, but peacemaking remains a largely Western prerogative. Often the political interest in interreligious initiatives is founded on the misguided belief that liberal minded religious leaders will provide access to their more problematic co-religionists. This approach fails to see that religions are subject to the same power battles and competing factions as any secular organization. The main problem, it seems to us, is that religion is such a fuzzy category. It encompasses international mass organizations such as the Catholic Church with 1.3 billion members and a fragmented Buddhist network organization of monasteries and loosely affiliated lay persons, and treats Pentecostal churches and Islamic traditions as if it were the same thing. Moreover, state sponsors seem to overlook the fact that religions are not monolithic structures with large constituencies but consist of organizations of various shapes and sizes, often marred by internal battles between groups with incompatible values. ${ }^{29}$

Religious fundamentalists have a profound disdain for established politics and secular elites, and are reluctant partners in dialogue. In the meantime, they are often vicariously represented by their liberal co-religionists. However, such arrangements disregard the wider implications of ongoing power battles within religions, and raises serious questions about the efficacy of these fora. It rests on the false assumption that religious traditions are identifiable and discrete units, which gives a liberal Christian easy access to Christian fundamentalists. This approach, which sees 'Christian,' 'Muslim,' 'Buddhist,' 'Hindu,' or 'Jew' as identity labels, chooses to ignore the institutional diversity and the gap in values, worldviews, and norms which give rise to different religious organizations in the first place. In a situation where different groups compete for dominance of religious traditions as well more limited battle inside religious organizations, those who are reluctant to engage in interreligious dialogue are also more prone to be directly involved in interreligious conflicts. Their liberal co-religionists have no privileged access to their trust and engage in fruitful dialogue. Despite these shortcomings interreligious dialogue has become a part of the diplomatic tool-kit of problem resolution. After more than twenty years of interreligious dialogue, we may conclude that religious diplomacy has become a small but permanent fixture of international peacemaking, but to no miraculous effect. The problem is not the motivation or personal commitment of these religious diplomats, but the uncertainties surrounding their representativity and their goals, and the many unfounded underlying assumptions of these dialogues. 
For the Review of faith \& International affairs 2018. Professor Anne Stensvold, and Ingrid Vik, IKOS, University of Oslo

\section{References}

Anderson, Mary Elizabeth. 2006. Gustaf Widengren and the Swedish Lutheran Renaissance, Bern: Peter Land Publishing.

Bakkevig, Trond. 2017. Dagbøker fra Jerusalem. 20 år som brobygger mellom religion og politikk. Oslo: Kagge Forlag.

Banchoff, Thomas. 2012. 'Interreligious Dialogue and International Relations". In Timothy Samuel Shah, Alfred Stepan and Monica Duffy Toft eds. Rethinking Religion and World Affairs. Oxford: Oxford University Press.

Barnett, Michael. 2012. 'Where is the Religion? Humanitarianism, Faith and World affairs'. In Shah, Timothy, Samuel Alfred Stepan and Monica Duffy Toft eds. Rethinking Religion and World Affairs. Oxford: Oxford University Press.

Berger, Peter L. ed. 2010. Between Relativism and Fundamentalism. Religious Resources for a Middle Position. Grad Rapids: Eerdmans Publishing Company.

Fry, Karin. 2014. Beyond Religious Right and Secular Left Rhetoric. The Road to Compromise. Basingstoke: Palgrave-Macmillan.

Blackford, Russell. 2012. Freedom of Religion and the Secular State. Oxford: WileyBlackwell.

Brekke, Torkel. 2012. Fundamentalism. Prophesy and Protest in an Age of Globalization. New York: Cambridge University Press.

Diamond, Louise, and John W. McDonald. 1996. Multi-Track Diplomacy: A Systems Approach to Peace. New York: Kumarian Press.

Engelsviken, Tormod et al. eds. 2009. Mission to the world: Communicating the Gospel in the 21st Century: Essays in honour of Knud Jorgensen, Regnum Studies in Mission, Eugene (OR): Wipf \& Stock Publishers.

Gallarotti, Giulio, and Isam Al Filali. 2012. 'The Soft Power of Saudi Arabia.' International Studies, 49 (3\&4), pp. 233-261.

Gandhi, Mahatma. 1958. All Men Are Brothers. UNESCO. Available at http://unesdoc.unesco.org/images/0007/000710/071082eo.pdf.

Harpviken, Kristian Berg \& Røislien, Hanne Eggen. (2008). 'Faithful Brokers? Potentials and Pitfalls of Religion in Peacemaking', in Conflict Resolution Quarterly, 25(3), pp. 351-373.

Haynes, Jeffrey. 2014. Faith-based Organizations at the United Nations. Basingstoke: Palgrave-Macmillan.

Haynes, Jeffrey. 2016. Religious Transnational Actors and Soft Power. London: Routledge. 
For the Review of faith \& International affairs 2018. Professor Anne Stensvold, and Ingrid Vik, IKOS, University of Oslo

Haynes, Jeffrey. 2017. 'The United Nations Alliance of Civilisations and Improved Global Dialogue'. In Anne Stensvold ed. Religion, State and the United Nations. London: Routledge.

Hick, John. 1989. An Interpretation of Religion: Human Responses to the Transcendent. New Haven, Connecticut: Yale University Press.

Horsfjord, Vebjørn. 2017. "Negotiating Traditional Values: The Russian Orthodox Church at the UNHCR. In Anne Stensvold ed. Religion, State and the United nations. London:

Routledge.

Hurd, Elizabeth Shakman. 2008. The Politics of Secularism in International Relations. Princeton NJ: Princeton University Press.

Johnston, Douglas. 1995. Religion, the Missing Dimension of Statecraft, Oxford: Oxford University Press.

Johnston, Douglas. 2003. Faith-Based Diplomacy. Trumping Realpolitik. Oxford: Oxford University Press.

Jonson, Jon. 2016. Nathan Soderblom: Called to Serve. Grand Rapids: Eerdmans Publishing.

Khatami, Seyyed Mohammad. 2001. 'Presentation', in Dialogue Among Civilizations. The Roundtable on the Eve of United Nations Millennium Summit, pp. 23-30. UNESCO Publishing.

Lederach, John Paul. 1997. Building Peace. Sustainable Reconciliation in Divided Societies. Washington (DC): United States Institute of Peace.

Lehmann, Karsten. 2015. Religious Presence in the Context of the United Nations Organization. London: Routledge.

Masuzawa, Tokomo. 2005. The Invention of World Religions, Chicago: Chicago University Press.

Meylan, Nicolas. 2017. Mana: A History of a Western Category. Leiden: Brill.

Miller, Donald. 2009. 'Progressive Pentecostalism: An Emergent Trend in Global Christianity'. Journal of Beliefs \& Values. Available at http://www-tandfonlinecom.nwulib.nwu.ac.za/doi/pdf/10.1080/13617670903371571

Miller, D.E. \& Yamamori, T. 2007. Global Pentecostalism: The New Face of Christian Social Engagement. Berkeley, LA: University of California Press.

Montville, Joseph V. 1992. 'Transnationalism and the Role of Track-Two Diplomacy.' In Approaches to Peace: An Intellectual Map, W.E. Thompson ed., Washington, DC: United States Institute of Peace.

Nan, Susan. 2003. 'Track I Diplomacy'. In Beyond Intractability, Guy Burgess and Heidi Burgess eds. Boulder (CO): University of Colorado. 
For the Review of faith \& International affairs 2018. Professor Anne Stensvold, and Ingrid Vik, IKOS, University of Oslo

Nostra Aetate: Declaration on the Relation of the Church to Other Religions. 1965. Available at http://www.vatican.va/archive/hist_councils/ii_vatican_council/documents/vat-

ii_decl_19651028_nostra-aetate_en.html

Neufeldt, Reina C. 2011. 'Interfaith Dialogue: Assessing Theories of Change.' Peace and Change. A Journal of Peace Research. 36 (3) pp. 344-372.

Riccardi, Andrea. 1997. Sant'Egidio Roma e Il Mondo. Alba: Edizioni San Paolo.

Said, Abdul Aziz and Charles Lerche. 1995. Concepts of International Politics in a Global Perspective. Englewood Cliffs (NJ): Prentice Hall

Saunders, Harold. 1991. 'Officials and Citizens in International Relations'. In The Psychodynamics of International Relations, Vol. 2, Unofficial Diplomacy at Work, Vamik D. Volkan, Joseph P. Montville and Demetrios A. Julius eds., pp. 41-69.

Shah, Timothy Samuel. 2000. 'Making the Christian World Safe for Liberalism: From Grotius to Rawls". The Political Quarterly 71, no. s1 (2000): 121-139.

Sharpe, Eric J. 1995. Comparative Religion. A History. London: Duckworth.

Skorini, Heini and Marie Juul Petersen. 2017. 'Hate Speech and Holy Prophets: Tracing the OIC's Strategies to Protect Religion at the UN'. In Anne Stensvold ed. Religion, State and the United Nations. London: Routledge.

Stanley, Brian. 2009. The World Missionary Conference, 1910 Edinburgh.

William B. Eerdman Publishing Company.

Stausberg, Michael. 2017. 'The Sacred, the Holy, the Numinous - and Religion: On the Emergence and Early History of a Terminological Constellation", Religion, 47(4), pp. 557590.

Stensvold, Anne. 2017. 'Religion, State and Symbol Politic: The Catholic Church at the United Nations", in Anne Stensvold ed. Religion, State and the United Nations. London: Routledge.

Söderblom, Nathan. 1914. Naturlig Religion Och Religionshistoria : En Historik Och ett Program, Stockholm: Bonniers.

Söderblom, Nathan. 1929. 'The Role of the Church in Peace Building'. Nobel lecture delivered on the 10th December 1929, available at https://www.nobelprize.org/nobel_prizes/peace/laureates/1930/soderblom-lecture.html

Thomas, Norman. 2010. Missions and Unity. Lessons from History 1792-2010. Cascade Books, Eugene (OR): Wipf \& Stock Publishers.

Twiss, Sumner B. 1990. 'The Philosophy of Religious Pluralism: A Critical Appraisal of Hick and His Critics", The Journal of Religion, 70(4) pp.533-568. 
For the Review of faith \& International affairs 2018. Professor Anne Stensvold, and Ingrid Vik, IKOS, University of Oslo

\author{
Vik, Ingrid and Cecilie Endresen. 2017. 'Norway, Religion and the United Nations'. In Anne \\ Stensvold ed. Religion, State and the United Nations. London: Routledge.
}

${ }^{1}$ Curiously the 1893 World Parliament of Religions was a staged celebration of religious pluralism is also
counted as a seminal event in the development of the History of religion or Comparative religion or the study
scientific of religion (Sharpe 1975, 138-40).
${ }^{2}$ Vik's work experience includes, in addition to working for the Norwegian Ministry of Foreign affairs (Balkan
section), consultancy on several international (Norwegian funded) interreligious dialogue processes. Vik has also
been an observatory participant at international conferences with political and religious actors under the auspices
of the UN, and events organized by actors such as former Iranian Prime Minister Mohammed Khatami.
${ }^{3}$ On second track diplomacy see also Saunders 1991,50; Montville 1992,255; Diamond and McDonald 1996.

Track one diplomacy is commonly described as official diplomacy involving state diplomats, high-level political and military leaders. See e.g. Said et al. 1995,69 and Nan 2003,1.

${ }^{4}$ Interview with Bondevik in Oslo 9th January 2018. Their time in political office overlapped: Bondevik was Norwegian prime minister (1997-2005), Khatami the president of Iran (1997-2005) and met several times. Today Bondevik leads his own NGO, Oslo Center for peace and human rights, while Khatami's NGO, Conversation among civilisations has been inactive since 2009 when Khatami was effectively placed in house arrest.

5 The Jordanian Interfaith Coexistence Research Centre, a non-governmental organization promoting peaceful religious coexistence.

${ }^{6}$ The Church of Norway has been a state church since the Lutheran Reformation in 1537. An act approved in 2016 created the Church of Norway as an independent legal entity, effective from 1 January 2017.

${ }^{7}$ Women Protestant ministers and Catholic nuns are virtually absent from interreligious peace talks. Whether this is due to the systematic exclusion (with a few exceptions) of women from religious leadership, or has something to do with the fact that international diplomacy was also a strictly male activity until a few decades ago we cannot say.

${ }^{8}$ Bakkevig 2017,18 (our translation). This is not to say that that expert knowledge make professional diplomats immune to the potentially irrational effects of personal emotions and private experiences, but this falls outside the scope of this article.

${ }^{9}$ Cited in Engelsviken 2009,252 (our translation). Kjell Magne Bondvik is a former Norwegian Prime Minister (1997-2000 and 2001-2005) and founder of the Oslo Centre for Peace and Human Rights (2006-). He has a theological education and is an ordained priest in the Norwegian Lutheran church (1979).

${ }^{10}$ Catholic diplomats, or rather diplomats of the Vatican State (more correctly, diplomats of the Holy See), are an exception, as they are both religious leaders as well as servents of a religious state in which the are recognized as citizens in virtue of their religious status. When it comes to other religious states (theocracies) they respect the difference between a secular profession such as diplomacy and religious expertise. Hence a country like Iran effectively separates the state department's diplomacy from religion.

${ }^{11}$ Today Söderblom's inheritance is kept alive in the philosophy of religion, notably in phenomenology and John Hick's philosophy of religious pluralism. His affinity with Söderblom is strikingly explained by Sumner B. Twiss: "Hick's theory of religious pluralism advances and defends the hypothesis of a noumenal transcendent divine reality (in itself infinite and unknowable) underlying and serving as the ultimate referent of the diverse phenomena of religion" (1990, 534).

${ }^{12}$ Norman Thomas traces its main inspiration back to the 1910 Edinburgh World Mission Congress (Thomas 2010,57), which is usually referred to as a precursor of interreligious dialogue (Banchoff (2012).

${ }^{13}$ Definition presented in Hasting's Encyclopedia of religion and ethics $(1914,731)$ Here cited from. Jonson $(2016,180)$.

${ }^{14}$ An even more influential contributor of perennialist theory within Protestant theology is the German theologian Rudolph Otto. A friend of Söderblom, Otto's famous work, Das Heilige, was published in 1917.

15 The Lausanne movement also draws its historical roots back to The World Missionary Conference in Edinburgh in 1910, which is also counted as a precursor of the Ecumenical Council (1930), a forerunner of the WCC (Thomas 2010,57). See the self presentation at the Lausanne Movement's home page https://www.lausanne.org/content/lga/2017-07/reaching-muslims-music-bridge-building-lesson-pakistan ${ }^{16}$ In research literature the split in world view and values is referred to as liberal/conservative (Blackford 2012) or relativism versus fundamentalism (Berger 2010).

${ }^{17}$ In multi-confessional USA the split among Christian churches amounts to a fight for dominance and power to define American society. What is understood as a good Christian in contemporary USA is largely associated with right wing value politics focusing on a few rallying points such as legal abortion and gay marriage, whereas poverty and justice are causes associated with the irreligious left (Fry 2014,113-115). 
For the Review of faith \& International affairs 2018. Professor Anne Stensvold, and Ingrid Vik, IKOS, University of Oslo

\footnotetext{
${ }^{18}$ Not all Pentecostal churches belong to the fundamentalist pole. There are also socially progressive Pentecostal churches, and according to Donald Miller this is a growing trend in American Pentecostalism.

${ }^{19}$ http://www.pewresearch.org/fact-tank/2017/10/27/500-years-after-the-reformation-5-facts-about-protestantsaround-the-world/

${ }^{20}$ Together with conservative Muslim countries and seriously challenges the liberal-democratic order represented by the UN (Skorini and Petersen 2017).

${ }^{21}$ https://www.theguardian.com/world/2015/feb/17/iranian-media-banned-from-mentioning-mohammad-khatami However, Kathami can still communicate with the outside world - albeit under heavy sensorship. In the 2017 election he supported the re-election of Rohani. See https://www.voanews.com/a/iran-khatamirouhani/3851117.html

${ }^{22}$ The correct translation from Persian is not 'dialogue' but conversation between civilisations. Thanks to Nazaneen Shamloo for this information.

${ }^{23}$ The centre's web page emphasises international collaborators, e.g. the Catholic Church and several UN agencies https://www.kaiciid.org/who-we-are

${ }^{24}$ Opening Address for the World Day of Prayer for Peace, Basilica of Santa Maria degli Angeli, Assisi, 27

October 1986, quotation from L'Osservatore Romano, 3 November 1986, p. 1. Here cited from Cardinal Tarcisio Bertone. 2011. "SDB From Assisi 1986 to Assisi 2011, the Meaning of a Journey", L'Osservatore Romano Weekly Edition in English 20 July 2011, page 6, available at http://www.ewtn.com/library/HUMANITY/86assisi11.htm (accessed 29th Nov. 2017).

${ }^{25}$ An overview of countries with diplomatic relations with the Catholic Church in its role as Papal State are available from the home page of the Holy See Mission http://www.holyseemission.org/contents/mission/diplomatic-relations-of-the-holy-see.php About the pope's engagement in international politics, see Stensvold 2017.

${ }^{26}$ Phone interview with Ingrid Vik, 16th of December 2017.

${ }^{27}$ In an interview on the 5th September 2017 Shaun Casy, former special representative for religion and global affairs, lamented the closing of the office, and transfer half of the 30 staff members to the Office of International Religious Freedom (IRF), which has a narrow mandate to compile and edit an annual report on the state of religious freedom worldwide. See Religion and Politics Newsletter, Washington University St. Louis available at http://religionandpolitics.org/2017/09/05/how-the-state-department-has-sidelined-religions-role-in-diplomacy/

${ }^{28}$ The concept of world religion relies on a huge generalisation an is highly disputed in the study of religion. Cf. the seminal work of Tomoko Musuzawa (2005).

${ }^{29}$ In the Catholic Church the problem of conflicting values is exemplified by the clash between official church policy and the Catholic for Choice, a liberal minded catholic organization critical of official church policy on contraception, divorce, and abortion (Stensvold 2017, 99).
} 